\title{
Effect of nitrite on immune response of Taiwan abalone Haliotis diversicolor supertexta and its susceptibility to Vibrio parahaemolyticus
}

\author{
Winton Cheng ${ }^{1}$, I-Shan Hsiao ${ }^{2}$, Jiann-Chu Chen ${ }^{3, *}$ \\ ${ }^{1}$ Department of Aquaculture and ${ }^{2}$ Institute of Tropical Agriculture, National Pingtung University of Science and Technology, \\ Pingtung, Taiwan, 912, ROC \\ ${ }^{3}$ Department of Aquaculture, College of Life and Resource Sciences, National Taiwan Ocean University, \\ Keelung, Taiwan, 202, ROC
}

\begin{abstract}
Taiwan abalones Haliotis diversicolor supertexta held in $30 \%$ seawater and $26^{\circ} \mathrm{C}$ were injected with tryptic soy broth (TSB)-grown Vibrio parahaemolyticus $\left(1.6 \times 10^{5} \mathrm{CFU}\right.$ [colony-forming units] abalone $\mathrm{e}^{-1}$ ), and then placed in water containing different concentrations of nitrite- $\mathrm{N}$ (nitrite as nitrogen): $0.01 \mathrm{mg} \mathrm{l}^{-1}$ (control), 1.05, 3.04, 5.10 and $10.06 \mathrm{mg} \mathrm{l}^{-1}$. Mortality of the abalones increased in direct parallel to ambient nitrite- $\mathrm{N}$ concentration. Over 12 to $48 \mathrm{~h}$, the mortality of $V$. parahaemolyticus-injected abalones held in $3.04 \mathrm{mg} \mathrm{l}^{-1}$ nitrite- $\mathrm{N}$ was significantly higher than that of abalones in the control solution. Abalones that had been exposed to control, 0.96, 2.95, 5.03 and $10.16 \mathrm{mg} \mathrm{l}^{-1}$ nitrite- $\mathrm{N}$ for 24,72 and $120 \mathrm{~h}$ were examined for THC (total hemocyte count), phenoloxidase activity, respiratory bursts (release of superoxide anion), phagocytic activity, and clearance efficiency of $V$. parahaemolyticus. The THC increased in abalone after $72 \mathrm{~h}$ exposure to 0.96 and $2.95 \mathrm{mg}$ $\mathrm{l}^{-1}$ nitrite- $\mathrm{N}$, but decreased in abalones after $24 \mathrm{~h}$ exposure to 5.03 and $10.16 \mathrm{mg} \mathrm{l}^{-1}$ nitrite-N. Phenoloxidase activity and respiratory bursts increased, while phagocytic activity and clearance efficiency decreased in abalones exposed to $\geq 0.96 \mathrm{mg} \mathrm{l}^{-1}$ nitrite-N for $24 \mathrm{~h}$. It is concluded that nitrite-N in water at concentrations as low as $0.96 \mathrm{mg} \mathrm{l}^{-1}$ weakens the immune response and increases mortality of $H$. diversicolor supertexta infected with $V$. parahaemolyticus.
\end{abstract}

KEY WORDS: Haliotis diversicolor supertexta - Vibrio parahaemolyticus · Nitrite $\cdot$ Challenge · Phenoloxidase activity $\cdot$ Respiratory burst $\cdot$ Phagocytic activity $\cdot$ Clearance efficiency

\section{INTRODUCTION}

Taiwan abalone Haliotis diversicolor supertexta is commercially important in Taiwan as well as on the SE coast of China mainland as a primary culture species. Chen (1984) reported that salinity in the range of 30 to $35 \%$ and temperature in the range of 24 to $30^{\circ} \mathrm{C}$ were the optimal levels for growth in this species. Culture of $H$. diversiocolor supertexta has expanded greatly since 1986 due to successful artificial propagation and development of multiple-tier basket systems in grow-out farms (Yang \& Ting 1986, Chen \& Lee 1999).

Since late 2000, there has been mass mortality of abalones reared in the multiple-tier basket system in grow-out farms, and settlement failure of spat larvae in nursery ponds. The bacteria Vibrio parahaemolyticus and $V$. alginolytius isolated from the hemolymph of moribund abalones, have been demonstrated to cause outbreaks of vibriosis associated with warm temperature (Liu et al. 2000, Lee et al. 2001).

The pond water in the multiple-tier basket system often becomes hypoxic, and high concentrations of ammonia may accumulate due to decomposition of organic matters such as unconsumed food and feces, and ammonia in excreta. Nitrite is an intermediate product during bacterial nitrification of ammonia. Elevated concentrations of ammonia have been reported to increase oxygen consumption of the greenlip abalone Haliotis 
laevigata (Harris et al. 1998), and to decrease the food consumption and growth rate of the ezo abalones $H$. discus hannai and H. laevigata (Sano \& Maniwa 1962, Harris et al. 1998). Ammonia and nitrite have also been reported to affect the immune response of the blue shrimp Litopenaeus stylirosyris (Le Moullac \& Haffner 2000), the white shrimp L. vannamei (Liu \& Chen 2004), and the freshwater prawn Macrobrachium rosenbergii (Cheng \& Chen 2002, Cheng et al. 2002).

In molluscs, agranular hemocytes (hyalinocytes) and granular hemocytes (granulocytes) are considered to be 2 distinct cell types (Bachère et al. 1995). They are involved in phagocytosis, an important process in eliminating microorganisms or foreign particles (Bayne 1990). During phagocytosis, contact with a pathogen activates the host's NADPH oxidase which, in turn, increases oxygen consumption and produces several species of reactive oxygen intermediates (ROIs) including the superoxide anion $\left(\mathrm{O}_{2}^{-}\right)$, hydrogen peroxide $\left(\mathrm{H}_{2} \mathrm{O}_{2}\right)$, singlet oxygen $\left({ }^{1} \mathrm{O}_{2}\right)$ and hydroxyl radical $(\mathrm{OH} \bullet)$ (Klebanoff 1982, Roch 1999). Superoxide anion is the first product released by respiratory activity bursts, and plays an important role in microbicidal activity. Hemocytes are also involved in the production of melanin via the prophenoloxidase system, which is an important component of the cellular defense reaction (Söderhäll et al. 1996).

Environmental physico-chemical parameters such as salinity and hypoxia, and pollutants such as $\mathrm{Cu}^{2+}$ and pentachlorophenol have been reported to affect the immune responses, including circulating hemocytes, phenoloxidase activity, respiratory bursts, phagocytosis and clearance efficiency in the red abalone Haliotis rufescens, the black abalone $H$. cracherodii and the Taiwan abalone $H$. diversicolor supertexta (Chen \& Yang 1996, Martello et al. 2000, Cheng et al. 2004a,b). It is assumed that increased concentrations of ammonia and nitrite weaken the immune system of $H$. diversicolor supertexta, and lead to its susceptibility to Vibrio infection. Therefore, this study examine, the effect of nitrite on the susceptibility of $H$. diversicolor supertexta to $V$. parahaemolyticus and the effect of nitrite on the immune response of $H$. diversicolor supertexta. For the latter purpose, we examined total hemocyte count (THC), phenoloxidase activity, respiratory bursts (release of superoxide anion), and the phagocytic activity and clearance efficiency of $H$. diversicolor supertexta infected with $V$. parahaemolyticus.

\section{MATERIALS AND METHODS}

Haliotis diversicolor supertexta. $H$. diversicolor supertexta were obtained from a commercial farm in Kaohsiung, and were acclimated in the laboratory at a salinity of $30 \%$ for $2 \mathrm{wk}$ at room temperature prior to experimentation. Shell length of the abalones ranged from 3.0 to $3.4 \mathrm{~cm}$ (average $3.36 \pm 0.96 \mathrm{~cm}$ ), and body weight from 3.0 to $4.5 \mathrm{~g}$ (average of $3.36 \pm 0.43 \mathrm{~g}$ ), with no significant difference among the treatments. During the acclimation period, the abalones were fed the marine alga Gracilaria tenuistipitata daily.

Vibrio parahaemolyticus. The bacterium V. parahaemolyticus, isolated from moribund abalones and demonstrated to cause 'withering syndrome', was used in the study (Liu et al. 2000). It was cultured in $50 \mathrm{ml}$ tryptic soy broth (TSB) supplemented with $3 \% \mathrm{NaCl}$ (TSB, Difco) for $24 \mathrm{~h}$ at $30^{\circ} \mathrm{C}$, and then centrifuged at $7155 \times g$ for $15 \mathrm{~min}$ at $4^{\circ} \mathrm{C}$. The supernatant fluid was removed and the bacterial pellet was re-suspended in saline solution $(0.85 \% \mathrm{NaCl})$ at concentrations of $8 \times$ $10^{6}$ and $5 \times 10^{8}$ colony-forming units (CFU) $\mathrm{ml}^{-1}$ as the stock bacterial suspension for injection challenge and tests of phagocytic activity and clearance efficiency.

Effect of nitrite on susceptibility of Haliotis diversicolor supertexta to Vibrio parahaemolyticus. We injected $20 \mu \mathrm{l}$ of bacterial suspension $\left(8 \times 10^{6} \mathrm{CFU} \mathrm{ml}{ }^{-1}\right)$ into the pallial sinus of each abalone with a sterile syringe (Chen 1996, Martello et al. 2000). Challenge tests at a dose of $1.6 \times 10^{5} \mathrm{CFU}$ abalone $^{-1}$ were conducted in triplicate. The test and control groups comprised 10 abalones each. After injection, each group of 10 abalones was kept in 151 PVC tanks (10 abalones each) containing 101 of water with different concentrations of nitrite- $\mathrm{N}$ (zero control and 1, 3,5 and $10 \mathrm{mg}$ $\mathrm{l}^{-1}$ ). The test solutions were renewed daily, and the experiment lasted $96 \mathrm{~h}$. The actual measured mean concentrations of nitrite- $\mathrm{N}$ in each test solution were 0.01 (control), 1.05, 3.04, 5.10 and $10.06 \mathrm{mg} \mathrm{l}^{-1}$ nitrite$\mathrm{N}$, respectively (Bendschneider \& Robinson 1952). The abalone were fed Gracilaria tenuistipitata and observed for $96 \mathrm{~h}$. During the experiment, water salinity and temperature were maintained at $30 \%$ and $26 \pm$ $1^{\circ} \mathrm{C}$. Control abalones were injected with an equal volume of sterile saline solution and exposed to the various test solutions. Abalones injected with an equal volume of sterile saline solution $(0.85 \% \mathrm{NaCl})$ and kept in $10.06 \mathrm{mg} \mathrm{l}^{-1}$ nitrite-N served as unchallenged controls (see Table 1). The $\mathrm{LC}_{50}$ (median lethal concentration) of nitrite- $\mathrm{N}$ was determined using the computer program of Trevors \& Lusty (1985).

Effect of nitrite on immune response of Haliotis diversicolor supertexta. For hemocyte counts and enzyme-activity assays, $H$. diversicolor supertexta were placed in 8 replicates of 20 l PVC tanks (1 abalone each). Each tank contained $10 \mathrm{l}$ of water with different concentrations of nitrite-N (zero control and 1, 3, 5 and $10 \mathrm{mg} \mathrm{l}^{-1}$ ) that was renewed daily for $5 \mathrm{~d}(120 \mathrm{~h})$. The actual measured mean concentrations for each concentration of nitrite- $\mathrm{N}$ in each test solution were 0.01 (con- 
trol), 0.96, 2.95, 5.03 and $10.16 \mathrm{mg} \mathrm{l}^{-1}$ nitrite-N, respectively (Bendschneider \& Robinson 1952).

Hemolymph was sampled individually at the beginning of the test, and after 24, 72 and $120 \mathrm{~h}$. Hemolymph $(100 \mu \mathrm{l})$ was withdrawn from the pallial sinus of each abalone with a $1 \mathrm{ml}$ sterile syringe ( 25 gauge) containing $100 \mu \mathrm{lBS}$ (phosphate buffer saline) (0.01 M, osmolality 980 mOsm kg${ }^{-1}, \mathrm{pH}$ 7.4). A drop of diluted hemolymph mixture was placed on a hemocytometer, and a THC was made under an inverted phase-contrast microscope (Leica DMIL, Leica Microsystems Wetzlar); the remainder of the mixture was used for subsequent tests.

Phenoloxidase activity of hemocytes was measured spectrophotometrically by recording the formation of dopachrome produced from L-dihydroxyphenylalanine (L-DOPA) (Coles \& Pipe 1994). Briefly, $100 \mu \mathrm{l}$ of diluted hemolymph in PSB was deposited in triplicate in 96-well microplates, and then centrifuged at $300 \times g$ for $15 \mathrm{~min}$. The supernatant fluid was discarded, and then $100 \mu \mathrm{l}$ of sodium alginate $\left(0.5 \mathrm{mg} \mathrm{ml}^{-1}\right.$ in PSB, serving as an activator) was added, and allowed to react for $30 \mathrm{~min}$ at 26 to $27^{\circ} \mathrm{C}$ (Asokan et al. 1997). We then added $50 \mu \mathrm{l}$ of LDOPA (3 $\mathrm{mg} \mathrm{ml}^{-1}$ in PBS) (as receptor), and allowed the hemolymph to react for $10 \mathrm{~min}$. The optical density at $490 \mathrm{~nm}$ was measured using a microplate reader (Model VERSAmax, Molecular Devices). The control solution, which consisted of $100 \mu \mathrm{l}$ of hemolymph, $100 \mu \mathrm{lBS}$ (to replace the sodium alginate) and $50 \mu \mathrm{L}$-DOPA, was used to measure the background phenoloxidase activity in all test conditions. The optical density values corresponding to the background phenoloxidase activity were in the range 0.02 to 0.04 . The optical density of the phenoloxidase activity of the abalones under all test conditions was expressed as the amount of dopachrome formed in $50 \mu$ l hemolymph.

The respiratory burst activity of the hemocytes was quantified by using the reduction of nitroblue tetrazolium (NBT) to formazan as a measure of superoxide anion, as described previously by Song \& Hsieh (1994). Briefly, $100 \mu \mathrm{l}$ of diluted hemolymph in PBS solution were deposited in triplicate onto microplates previously coated with $100 \mu \mathrm{l}$ poly-L-lysine solution $(0.2 \%)$ to improve cell adhesion. Microplates were centrifuged at $300 \times g$ for $15 \mathrm{~min}$. Plasma was removed and $100 \mu \mathrm{l}$ sodium alginate $\left(0.2 \mathrm{mg} \mathrm{ml}^{-1}\right.$ in PBS) were added, and allowed to react for $30 \mathrm{~min}$ at 26 to $27^{\circ} \mathrm{C}$. The sodium alginate was discarded and the hemocytes were stained with $100 \mu \mathrm{l}$ NBT solution $(0.3 \%)$ for $30 \mathrm{~min}$ at room temperature. The NBT solution was removed and the hemocytes were fixed with $100 \%$ methanol, and washed 3 times with $100 \mu \mathrm{l} 70 \%$ methanol and air-dried. The formazan was dissolved by the addition of $120 \mu \mathrm{l} 2 \mathrm{M} \mathrm{KOH}$ and $140 \mu \mathrm{l}$ dimethyl sulfoxide (DMSO). The optical density at $630 \mathrm{~nm}$ was measured using a microplate reader. Respiratory burst was expressed as the amount of NBT reduction in $50 \mu \mathrm{l}$ of hemolymph.

To measure bacterial clearance and phagocytic activity, after $0,24,72$ and $120 \mathrm{~h}$ exposure to different concentrations of nitrite- $\mathrm{N}$, we injected $20 \mu \mathrm{l}$ bacterial suspension $\left(5 \times 10^{8} \mathrm{CFU} \mathrm{ml}^{-1}\right.$ in $\left.0.85 \% \mathrm{NaCl}\right)$ into the pallial sinus of the abalones, resulting in $1 \times 10^{7} \mathrm{CFU}$ abalone $^{-1}$. After injection, each abalone was held in a separate tank containing one of the test solutions for $3 \mathrm{~h}$ at $30 \%$ and $26 \pm 1^{\circ} \mathrm{C}$. We then collected $200 \mu \mathrm{l}$ of hemolymph from the pallial sinus and added $200 \mu$ of PBS (pH 7.4, $980 \mathrm{mOsm} \mathrm{kg}^{-1}$ ). This mixture was divided into 2 equal subsamples, one to measure phagocytic activity, the other to measure clearance efficiency.

Phagocytic activity was measured by the method of Weeks-Perkins et al. (1995). Briefly, $200 \mu \mathrm{l}$ of the diluted hemolymph sample were fixed with $200 \mu \mathrm{l}$ $0.1 \%$ paraformaldehyde for $30 \mathrm{~min}$ at $4^{\circ} \mathrm{C}$ to fix the hemocytes; the sample was then centrifuged at $800 \times g$ with a centrifuge (Model Z323, Hermle) at $4^{\circ} \mathrm{C}$. The precipitated hemocytes were washed with $0.4 \mathrm{ml}$ of sterile PBS. We then sampled $50 \mu \mathrm{l}$ of suspension, which was spread on a glass slide and placed in a cytospin centrifuge (Model Cytospin 3, Shandon) and centrifuged at $113 \times g$ for $3 \mathrm{~min}$. The slide was airdried, stained with Diff-Quick stain, and observed under a light microscope; 200 hemocytes were counted. Phagocytic activity was expressed as percentage phagocytosis:

$$
\% \text { phagocytosis }=[(\text { phagocytic hemocytes }) /
$$

Clearance efficiency was measured by the method of Adams (1991). Hemolymph was collected and diluted 200 -fold with sterile PBS. We spread $50 \mu$ l of diluted hemolymph on separate TSA (tryptic soy agar) plates, and incubated these at $30^{\circ} \mathrm{C}$ for $24 \mathrm{~h}$. Colonies were then counted with a colony counter. The number of colonies from abalones reared in the control solution at the beginning of the test served as the control group; the number of colonies from abalones exposed to different concentrations of nitrite- $\mathrm{N}$ after 24,72 and $120 \mathrm{~h}$ were the test groups. Clearance efficiency of Vibrio parahaemolyticus was calculated and expressed as percentage inhibition (PI):

$$
\begin{aligned}
\mathrm{PI}= & 100-[(\mathrm{CFU} \text { in test group }) / \\
& (\mathrm{CFU} \text { in control group })] \times 100
\end{aligned}
$$

Statistical analysis. Tukey's multiple comparison test was used to compare the significance of differences among treatments using SAS computer software (SAS Institute). The percentage data (from the susceptibility study) were normalized using arcsine transformation before analysis (statistically significant difference $=p<$ 0.05). 
Table 1. Haliotis diversicolor supertexta infected with Vibroio parahaemolyticus. Susceptibility (cumulative mortality, \%) of abalones exposed to different concentrations of ambient nitrite- $\mathrm{N}$ at $30 \%$ and $26^{\circ} \mathrm{C}$. Data in same column with different supercripts on right are significantly different $(\mathrm{p}<0.05)$ among time periods $(\mathrm{h})$, and data in same row with different superscripts on left are significantly different $(p<0.05)$ among treatments. Means \pm SE $(n=30$ abalones in each case)

\begin{tabular}{|c|c|c|c|c|c|c|c|}
\hline \multirow{2}{*}{$\begin{array}{l}\text { Bacterial dose } \\
\left(\text { CFU abalone }{ }^{-1}\right)\end{array}$} & \multirow{2}{*}{$\begin{array}{l}\text { Nitrite-N } \\
\left(\mathrm{mg} \mathrm{l}^{-1}\right)\end{array}$} & \multicolumn{6}{|c|}{-Time after challenge $(\mathrm{h})$} \\
\hline & & 6 & 12 & 24 & 48 & 72 & 96 \\
\hline Control $^{\mathrm{a}}$ & 10.06 & 0 & 0 & 0 & 0 & 0 & 0 \\
\hline $1.6 \times 10^{5}$ & Control $^{\mathrm{b}}$ & $\mathrm{d} 3.3 \pm 0.0^{\mathrm{y}}$ & ${ }^{\mathrm{d}} 6.7 \pm 6.7^{\mathrm{w}}$ & ${ }^{c} 13.3 \pm 3.3^{w}$ & b $26.7 \pm 6.7^{z}$ & a $36.7 \pm 5.8^{z}$ & a $36.7 \pm 5.8^{\mathrm{z}}$ \\
\hline $1.6 \times 10^{5}$ & 1.05 & ${ }^{\mathrm{c}} 6.7 \pm 6.7^{\mathrm{y}}$ & ${ }^{\mathrm{bc}} 13.3 \pm 8.8^{\mathrm{z}}$ & ${ }^{\mathrm{b}} 23.3 \pm 3.3^{\mathrm{z}}$ & a $36.7 \pm 3.3^{z}$ & ${ }^{\mathrm{a}} 40.0 \pm 5.8^{\mathrm{z}}$ & ${ }^{\mathrm{a}} 40.0 \pm 5.8^{\mathrm{z}}$ \\
\hline $1.6 \times 10^{5}$ & 3.04 & ${ }^{\mathrm{c}} 10.0 \pm 5.8^{\mathrm{xy}}$ & ${ }^{\mathrm{b}} 23.3 \pm 8.8^{\mathrm{y}}$ & ${ }^{\mathrm{b}} 30.0 \pm 5.8^{\mathrm{yz}}$ & ${ }^{\mathrm{ab}} 40.0 \pm 5.8^{\mathrm{y}}$ & ${ }^{\mathrm{a}} 46.7 \pm 8.8^{\mathrm{yz}}$ & ${ }^{\mathrm{a}} 46.7 \pm 8.8^{\mathrm{yz}}$ \\
\hline $1.6 \times 10^{5}$ & 5.10 & ${ }^{d} 13.3 \pm 3.3^{x}$ & ${ }^{\mathrm{c}} 26.7 \pm 3.3^{\mathrm{xy}}$ & $\mathrm{b}_{3} 36.7 \pm 6.7^{\mathrm{y}}$ & ${ }^{\mathrm{ab}} 46.7 \pm 6.7^{\mathrm{xy}}$ & ${ }^{\mathrm{a}} 53.3 \pm 6.7^{\mathrm{y}}$ & ${ }^{a} 53.3 \pm 6.7^{y}$ \\
\hline $1.6 \times 10^{5}$ & 10.06 & ${ }^{\mathrm{d}} 16.7 \pm 3.3^{\mathrm{x}}$ & ${ }^{\mathrm{c}} 30.0 \pm 5.8^{\mathrm{x}}$ & ${ }^{\mathrm{b}} 46.7 \pm 6.7^{\mathrm{x}}$ & ${ }^{\mathrm{b}} 56.7 \pm 6.7^{\mathrm{x}}$ & ${ }^{\mathrm{a}} 70.0 \pm 0.0^{\mathrm{x}}$ & ${ }^{\mathrm{a}} 70.0 \pm 0.0^{\mathrm{x}}$ \\
\hline
\end{tabular}
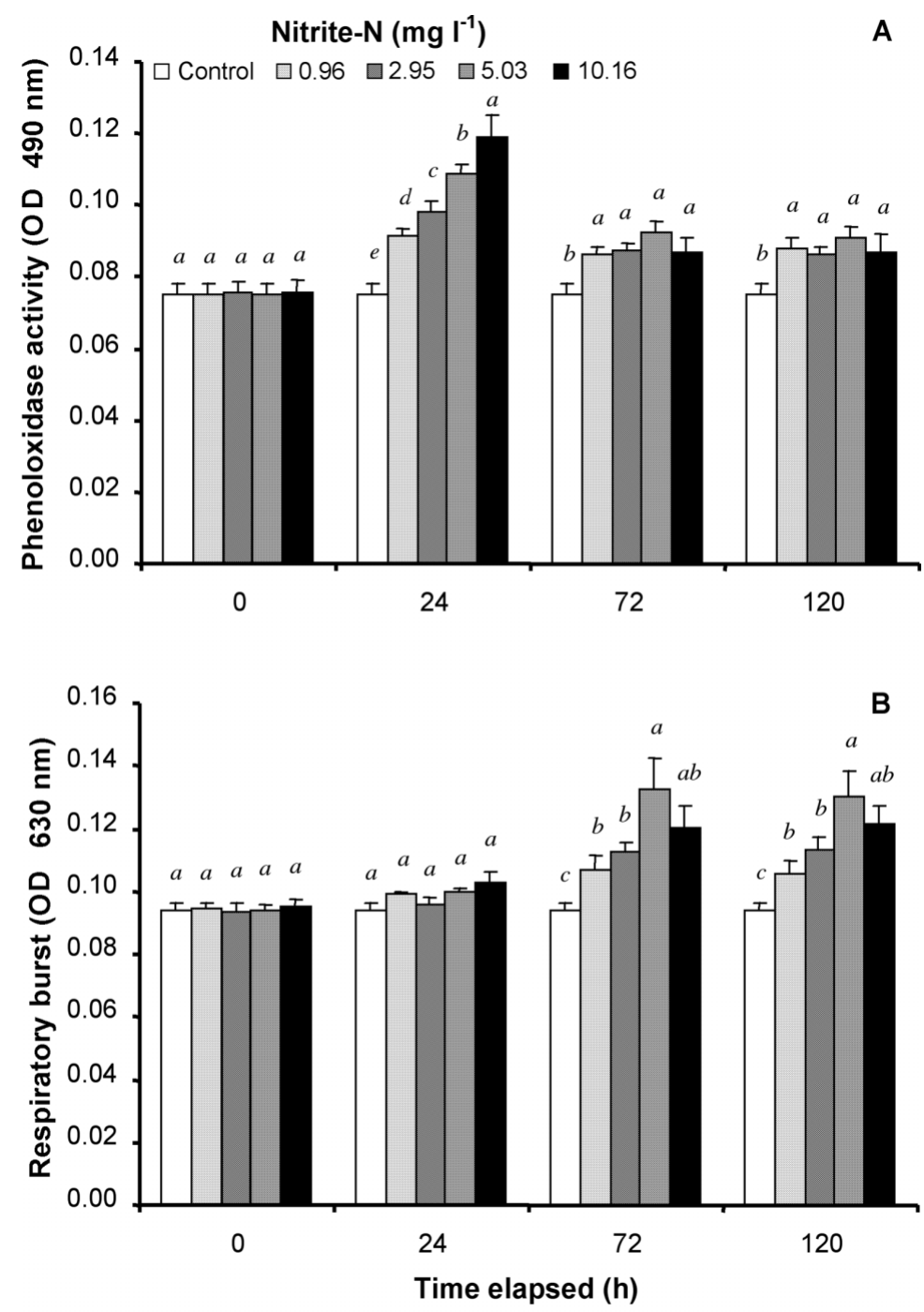

Fig. 1. Haliotis diversicolor supertexta. Mean $( \pm \mathrm{SE})(\mathrm{A})$ phenoloxidase activity and (B) respiratory burst in hemocytes after $0,24,72$ and $120 \mathrm{~h}$ exposure to nitrite-N. Each bar represents mean $( \pm \mathrm{SE})$ of 8 determinations. Values for same exposure time with different letters $=$ significant difference $(p<0.05)$ among treatments. OD: optical density

\section{RESULTS}

\section{Effect of nitrite on susceptibility of Haliotis diversicolor supertexta to Vibrio parahemolyticus}

All unchallenged control abalones survived. In contrast, mortality began to occur at $6 \mathrm{~h}$ in the challenged abalones. Cumulative mortality increased in direct parallel to ambient nitrite-N concentration. After $12 \mathrm{~h}$, the cumulative mortality of abalones in $1.05 \mathrm{mg} \mathrm{l}^{-1}$ nitrite- $\mathrm{N}$ was significantly higher than in the controls. Cumulative mortality over 72 to 96 h was $36.7,40.0$, 46.7, 53.3 and $70.0 \%$ for abalones in control, $1.05,3.04,5.10$ and $10.06 \mathrm{mg} \mathrm{l}^{-1}$ nitrite-N treatments, respectively (Table 1). The $48 \mathrm{~h}$ and $96 \mathrm{~h}$ $\mathrm{LC}_{50} \mathrm{~s}$ of nitrite-N for Haliotis diversicolor supertexta were 8.7 and $4.3 \mathrm{mg} \mathrm{l}^{-1}$, respectively.

\section{Effect of nitrite on immune response of Haliotis diversicolor supertexta}

There were no significant differences in THC for control abalones at and $26^{\circ} \mathrm{C}$ at the different sampling times; the mean $( \pm \mathrm{SE})$ varied from $206.0 \pm 19.4 \times 10^{4}$ to $210.2 \pm 14.6 \times 10^{4}$ cells ml$^{-1}$. The THC of abalones exposed to 0.96 and $2.95 \mathrm{mg} \mathrm{l}^{-1}$ nitrite- $\mathrm{N}$ for $72 \mathrm{~h}$ increased significantly by 32 and $23 \%$, respectively, while that of abalones exposed to 5.03 and $10.16 \mathrm{mg} \mathrm{l}^{-1}$ nitrite-N for $72 \mathrm{~h}$ decreased significantly by 26 and $47 \%$, respectively, as compared to the controls (Table 2).

No significant difference in phenoloxidase activity was observed among the control abalones at the beginning of the experiment and after 24,72 and $120 \mathrm{~h}$. After $24 \mathrm{~h}$, relative phe- 
Table 2. Haliotis diversicolor supertexta. Effect of different concentrations of ambient nitrite-N (mg l $\mathrm{l}^{-1}$ ) on THC (total hemocyte counts, $\left.\times 10^{4} \mathrm{ml}^{-1}\right)$. Data in same column with different superscripts on left are significantly different $(\mathrm{p}<0.05)$ among time periods (h), data in same row with different superscripts on right are significantly different $(\mathrm{p}<0.05)$ among treatments. Means \pm SE ( $\mathrm{n}=8$ abalones in each case)

\begin{tabular}{|c|c|c|c|c|c|}
\hline \multirow{2}{*}{ Sampling time (h) } & \multirow{2}{*}{ Control } & \multicolumn{4}{|c|}{ —Nitrite-N $\left(\mathrm{mg} \mathrm{l}^{-1}\right)$} \\
\hline & & 0.96 & 2.95 & 5.03 & 10.16 \\
\hline 0 & ${ }^{\mathrm{a}} 210.2 \pm 14.6^{\mathrm{x}}$ & ${ }^{\mathrm{b}} 210.2 \pm 14.6^{\mathrm{x}}$ & ${ }^{\mathrm{b}} 210.2 \pm 14.6^{\mathrm{x}}$ & ${ }^{\mathrm{a}} 210.2 \pm 14.6^{\mathrm{x}}$ & ${ }^{\mathrm{a}} 210.2 \pm 14.6^{\mathrm{x}}$ \\
\hline 24 & ${ }^{\mathrm{a}} 208.9 \pm 11.3^{\mathrm{x}}$ & ${ }^{\mathrm{b}} 205.1 \pm 28.5^{\mathrm{x}}$ & ${ }^{\mathrm{b}} 206.2 \pm 18.1^{\mathrm{x}}$ & ${ }^{\mathrm{b}} 143.0 \pm 11.3^{\mathrm{y}}$ & ${ }^{\mathrm{b}} 159.4 \pm 25.9^{\mathrm{y}}$ \\
\hline 72 & ${ }^{\mathrm{a}} 210.8 \pm 14.6^{\mathrm{y}}$ & ${ }^{\mathrm{a}} 277.4 \pm 13.0^{\mathrm{x}}$ & ${ }^{\mathrm{a}} 258.9 \pm 6.0^{\mathrm{x}}$ & ${ }^{b} 155.8 \pm 16.5^{y}$ & ${ }^{\mathrm{c}} 110.1 \pm 29.6^{\mathrm{z}}$ \\
\hline 120 & ${ }^{\mathrm{a}} 206.0 \pm 19.4^{\mathrm{y}}$ & ${ }^{\mathrm{a}} 294.0 \pm 19.6^{\mathrm{x}}$ & ${ }^{\mathrm{a}} 246.6 \pm 11.9^{\mathrm{x}}$ & ${ }^{\mathrm{b}} 143.0 \pm 24.0^{\mathrm{Y}}$ & ${ }^{\mathrm{c}} 105.8 \pm 24.2^{\mathrm{z}}$ \\
\hline
\end{tabular}

noloxidase activity (compared to activity of the controls) increased significantly (by 120, 127, 140 and $147 \%$ ) in abalones exposed to $0.96,2.95,5.03$ and $10.16 \mathrm{mg} \mathrm{l}^{-1}$ nitrite-N. After $120 \mathrm{~h}$, the relative phenoloxidase activity for abalones exposed to $0.96,2.95,5.03$ and $10.16 \mathrm{mg} \mathrm{l}^{-1}$ nitrite- $\mathrm{N}$ was 120 , 113, 117 and $107 \%$, respectively (Fig. 1A).

No significant difference in respiratory bursts was observed among the control abalones at the beginning of the experiment and after 24, 72 and $120 \mathrm{~h}$. After $72 \mathrm{~h}$, the relative respiratory bursts (compared to activity of the controls) of abalones exposed to $0.96,2.95,5.03$ and $10.16 \mathrm{mg} \mathrm{l}^{-1}$ nitrite$\mathrm{N}$ were 122,133, 150 and $128 \%$, respectively. After $120 \mathrm{~h}$, the respiratory bursts for abalones exposed to $0.96,2.95,5.03$ and $10.16 \mathrm{mg} \mathrm{l}^{-1}$ nitrite$\mathrm{N}$ were 117, 136, 144 and $133 \%$, respectively (Fig. 1B).

At time $0 \mathrm{~h}$, phagocytic activity was $13.5 \%$ in the controls. Phagocytic activity was inversely related to nitrite- $\mathrm{N}$ concentration. After $24 \mathrm{~h}$, phagocytic activity decreased significantly to 4.0 , $3.0,3.0$ and $2.8 \%$ in abalones exposed to 0.96 , $2.95,5.03$ and $10.16 \mathrm{mg} \mathrm{l}^{-1}$ nitrite-N, respectively (Fig. 2A).

Clearance efficiency was inversely related to nitrite-N concentration. After 24 to $120 \mathrm{~h}$, clearance efficiency of the controls was $15 \%$, while that of abalones exposed to 0.96, 2.95, 5.03 and $10.16 \mathrm{mg} \mathrm{l}^{-1}$ nitrite-N had decreased significantly to $-60,-100,-190$ and $-250 \%$, respectively, after $24 \mathrm{~h}$ (Fig. 2B).

\section{DISCUSSION}

Water temperature, salinity, dissolved oxygen, $\mathrm{pH}$ and nitrite have been reported to increase the susceptibility of the freshwater prawn Macrobrachium rosenbergii to the pathogen Lactococcus garvieae (Cheng \& Chen 1998, Cheng et al. 2002). In the present study, we found that the sus- ceptibility of Haliotis diversicolor supertexta to Vibrio parahaemolyticus increased in direct parallel to increasing ambient nitrite-N concentration. H. diversi-
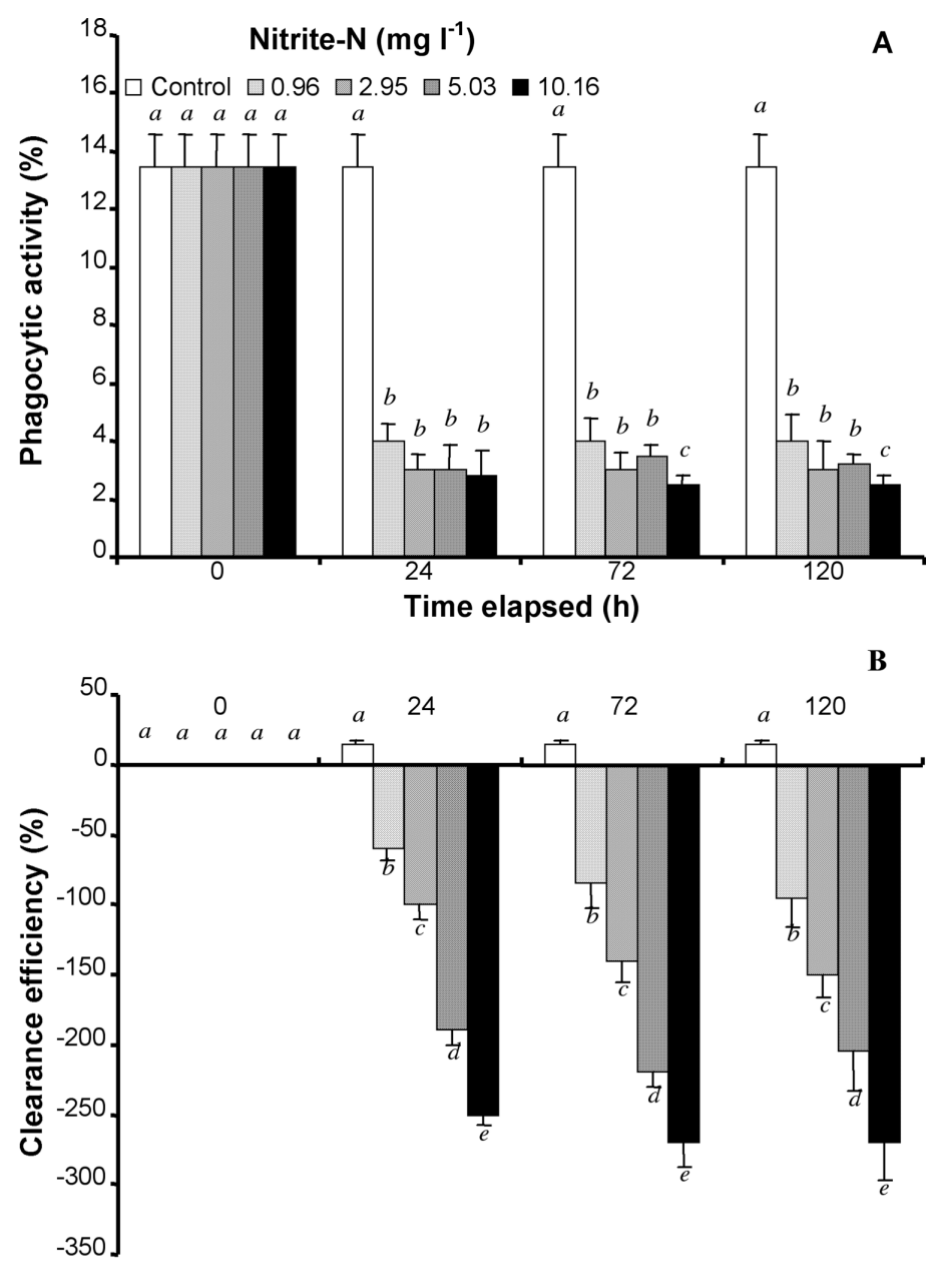

Fig. 2. Haliotis diversicolor supertexta. Mean $( \pm \mathrm{SE})(\mathrm{A})$ phagocytic activity and (B) clearance efficiency after 0, 24, 72 and $120 \mathrm{~h}$ exposure to different concentrations of nitrite-N. Each bar represents mean $( \pm \mathrm{SE})$ of 8 determinations. Values for same exposure time with different letters $=$ significant difference $(p<0.05)$ among treatments 
color supertexta was more susceptible to $V$. parahaemolyticus when abalones were transferred from $30 \%$ to 20,25 or $35 \%$ (Cheng et al. 2004a) and also when reared in medium containing $2.05 \mathrm{mg} \mathrm{l}^{-1}$ dissolved oxygen (Cheng et al. 2004b). It can be concluded that salinity changes, hypoxia and the presence of nitrite-N can trigger an outbreak of the disease by weakening the immune response of $H$. diversicolor supertexta.

No significant difference in THC was observed in the freshwater prawn Macrobrachium rosenbergii exposed to ambient ammonia- $\mathrm{N}$ in the range 0 to $3.18 \mathrm{mg} \mathrm{l}^{-1}$ for $7 \mathrm{~d}$ (Cheng \& Chen 2002), or exposed to ambient nitrite$\mathrm{N}$ in the range 0 to $1.68 \mathrm{mg} \mathrm{l}^{-1}$ for $7 \mathrm{~d}$ (Cheng et al. 2002). No significant difference in THC was observed in the white shrimp Litopenaeus vannamei following $7 \mathrm{~d}$ exposure to ambient ammonia- $\mathrm{N}$ in the range 0.01 to $21.60 \mathrm{mg} \mathrm{l}^{-1}$ (Liu \& Chen 2004). However, in the present study, THC increased in Haliotis diversicolor supertexta following $72 \mathrm{~h}$ exposure to 0.96 and $2.95 \mathrm{mg} \mathrm{l}^{-1}$ nitrite-N, but decreased following $24 \mathrm{~h}$ exposure to 5.03 and $10.16 \mathrm{mg} \mathrm{l}^{-1}$ nitrite-N. Phenoloxidase is stored in the secretory granules of semi-granular and granular hemocytes, whereas arganular hemocytes are involved in phgagocytoisis and the release of superoxide anion and other ROIs (Bachère et al. 1995). Further research is needed to clarify whether a change in DHC (differential hemocyte count) occurs in abalone under nitrite stress, and whether changes in THC and DHC result from cell proliferation, from leakage of cells from tissues into circulatory fluids, as a result of lysis, or through dilution of the hemolymph (Pipe \& Coles 1995).

In the present study, Haliotis diversicolor supertexta exposed to 5.03 and $10.16 \mathrm{mg} \mathrm{l}^{-1}$ nitrite- $\mathrm{N}$ decreased its THC, but increased its phenoloxidase activity. The blue shrimp Litopenaeus stylirostris exposed to $3 \mathrm{mg}$ $\mathrm{l}^{-1}$ ammonia decreased its THC by $51 \%$, but increased its phenoloxidase activity by $33 \%$ (Le Moullac \& Haffner 2000). A negative correlation between phenoloxidase activity and THC was observed in $L$. stylirostris following $24 \mathrm{~h}$ exposure to $1 \mathrm{mg} \mathrm{l}^{-1}$ DO (dissolved oxygen) (Le Moullac et al. 1998); in H. diversicolor supertexta following $24 \mathrm{~h}$ exposure to $2.05 \mathrm{mg} \mathrm{l}^{-1}$ DO (Cheng et al. 2004b); and in the common shrimp Crangon crangon following exposure to PCB (Smith \& Johnston 1992). It is known that the prophenoloxidase system is activated by serine protease (the prophenoloxidase activating enzyme, ppA), a serine protease activated by the microbial cell walls. The ppA can be regulated by 2 protease inhibitors, $\alpha_{2}$-macroglobulin (Hergenhahn \& Söderhäll 1985) and trypsin inhibitors such as pacifastin (Hergenhahn et al. 1987). It would seem likely that, following exposure to ambient nitrite$\mathrm{N}$ of $\geq 5 \mathrm{mg} \mathrm{l}^{-1}$, the abalone would have less antiprotease activity available to regulate the ppA.
The phenoloxidase activity of Litopenaeus vannamei decreased significantly after $1 \mathrm{~d}$ exposure to $5.24 \mathrm{mg}$ $\mathrm{l}^{-1}$ ammonia-N (Liu \& Chen 2004), while that of $L$. stylirostris exposed to $3.0 \mathrm{mg} \mathrm{l}^{-1}$ ammonia increased significantly (Le Moullac \& Haffner 2000). However, neither group of investigators reported the exposure times. In the present study, phenoloxidase activity of Haliotis diversicolor supertexta increased after 24, 72 and $120 \mathrm{~h}$ exposure to $\geq 0.96 \mathrm{mg} \mathrm{l}^{-1}$ nitrite-N. The transcript encoding prophenoloxidase and peroxinectin decreased by 60 and $50 \%$ when L. stylirostris were exposed to 1.5 and $3.0 \mathrm{mg} \mathrm{l}^{-1}$ ammonia, respectively, with a concomitant reduction in hemocyte count by 15 and $51 \%$ (Le Moullac \& Haffner 2000). L. vannamei transferred from 26 to $34^{\circ} \mathrm{C}$ decreased its amount of peroxinectin mRNA in $2 \mathrm{~d}$ (Liu et al. 2004). Therefore, the defense responses related to phenoloxidase and peroxinection may also be weakened at the level of gene expression in L. vannamei under nitrite stress.

Exposure of Macrobrachium rosenbergii to 1.15 and $1.68 \mathrm{mg} \mathrm{l}^{-1}$ nitrite- $\mathrm{N}$ for $168 \mathrm{~h}$ stimulated the production of superoxide anion (Cheng et al. 2002). In the present study, Haliotis diversicolor supertexta exposed to ambient nitrite- $\mathrm{N}$ at $\geq 0.96 \mathrm{mg} \mathrm{l}^{-1}$ for $72 \mathrm{~h}$ increased the release of superoxide anion. In our experiments it was not possible to distinguish whether the increase in superoxide anion resulted from increased activity of NADPH oxidase (responsible for producing the superoxide anion), or from decreased activity of superoxide dismutase (SOD) (responsible for scavenging the superoxide anion). A small increase in the superoxide anion is considered to increase immunity. However, too great an increase may be toxic to the host (Cheng \& Wang 2001). Further research is needed to examine the activities of enzymes such as SOD, catalase and peroxidase, and transport proteins such as ferritin and transferrin, which are capable of preventing production of hydroxyl radicals, as shown by Holmblad \& Söderhäll (1999) for abalones during ammonia exposure.

Phagocytosis in invertebrates can be affected by environmental parameters (Bayne 1990, Pipe \& Coles 1995). For example, elevated temperature has been reported to increase phagocytosis (Feng \& Feng 1974) and hemocyte activity (determined as the ability of hemocytes to adhere to fluorescent beads) in the American oyster Crassostrea virginica (Foley \& Cheng 1975). Phagocytic activity and clearance efficiency of Vibrio parahaemolyticus decreased in Haliotis diversicolor supertexta following $24 \mathrm{~h}$ exposure to $0.96,2.95$, 5.03 and $10.16 \mathrm{mg} \mathrm{l}^{-1}$ nitrite- $\mathrm{N}$. This correlated well with the increased susceptibility of $H$. diversicolor supertexta to $V$. parahaemolyticus when the abalones were under nitrite stress. It would be interesting to determine whether nitrite stress affects the production of anti-microbial peptides, such as mytilin and 
mytimicin observed in the mussels Mytilus edulis and M. galloprovincialis (Charlet et al. 1996) and Pacific oyster Crassostrea gigas (Hubert et al. 1996).

In conclusion, ambient nitrite decreased the resistance of Haliotis diversicolor supertexta to Vibrio parahaemolyticus. Ambient nitrite- $\mathrm{N}$ at a concentration of $0.96 \mathrm{mg} \mathrm{l}^{-1}$ increased the susceptibility of $H$. diversicolor supertexta by weakening its immune responses, e.g. by enhanced THC and phenoloxidase activity and a reduction in phagocytic activity and clearance efficiency of $V$. parahaemolyticus, together with an increase in the superoxide anion to levels possibly cytotoxic to the host.

Acknowledgements. The study was supported by a grant from the Agriculture Council (91-No-Ka-2.5.3-Yu-F2), Republic of China. We thank Dr. K. K. Lee and P. C. Liu for providing the bacterial strain and Miss C. S. Wang for her assistance in the experiment.

\section{LITERATURE CITED}

Adams A (1991) Response of penaeid shrimp to exposure to Vibrio species. Fish Shellfish Immunol 1:59-70

Asokan R, Arumugam M, Mullainadhan P (1997) Activation of prophenoloxidase in the plasma and haemocytes of the marine mussel Perna viridis Linnaeus. Dev Comp Immunol 21:1-12

Bachère E, Mialhe E, Noöl D, Boulo V, Morvan A, Rodriguez J (1995) Knowledge and research prospects in marine mollusc and crustacean immunology. Aquaculture 132:17-32

Bayne CJ (1990) Phagocytosis and non-self recognition in invertebrates: phagocytosis appears to be an ancient line of defense. BioScience 40:723-731

Bendschneider K, Robinson RJ (1952) A new spectrometric method for the determination of nitrite in the sea water. J Mar Res 11:87-96

Charlet M, Chernysh S, Philippe H, Hetrut C, Hoffmann J, Bulet P (1996) Innate immunity: isolation of several cysteine-rich antimicrobial peptides from the blood of a mollusk Mytilus edulis. J Biol Chem 271:21808-21813

Chen HC (1984) Recent innovations in cultivation of edible molluscs in Taiwan with special reference to the small abalone Haliotis diversicolor and the hard clam Metretrix lusoria. Aquaculture 39:11-27

Chen JC, Lee WC (1999) Growth of Taiwan abalone Haliotis diversicolor supertexta fed on Gracilaria tenuistipitata and artificial diet in a multiple-tier basket system. J Shellfish Res 18:627-635

Chen JH (1996) Hemolymph collection in abalone (Haliotis diversicolor). Acta Zool Taiwanica 7:61-71

Chen $\mathrm{JH}$, Yang HY (1996) The effect of $\mathrm{Cu}^{2+}$ on cellular immunity in abalone (Haliotis diversicolor). Acta Zool Taiwanica 7:51-59

Cheng W, Chen JC (1998) Enterococcus-like infections in Macrobrachium rosenbergii are exacerbated by high $\mathrm{pH}$ and temperature but reduced by low salinity. Dis Aquat Org 34:103-108

Cheng W, Chen JC (2002) The virulence of Enterococcus to freshwater prawn Macrobrachium rosenbergii and its immune resistance under ammonia stress. Fish Shellfish Immunol 12:97-109
Cheng W, Wang CH (2001) The susceptibility of the giant freshwater prawn Macrobrachium rosenbergii to Lactococcus garvieae and its resistance under copper sulfate stress. Dis Aquat Org 47:137-144

Cheng W, Liu CH, Chen JC (2002) Effect of nitrite on interaction between the giant freshwater prawn Macrobrachium rosenbergii and its pathogen Lactococcus garvieae. Dis Aquat Org 50:189-197

Cheng W, Juang FM, Chen JC (2004a) The immune response of Taiwan abalone Haliotis diversicolor supertexta and its susceptibility to Vibrio parahaemolyticus at different salinity levels. Fish Shellfish Immunol 16:295-306

Cheng, W, Li CH, Chen JC (2004b) Effects of dissolved oxygen on the immune response of Haliotis diversicolor supertexta and its susceptibility to Vibrio parahaemolyticus. Aquaculture 232:103-115

Coles JA, Pipe PK (1994) Phenoloxidase activity in the haemolymph and haemocytes of the marine mussel, Mytilus edulis. Fish Shellfish Immunol 4:337-352

Feng SY, Feng JS (1974) The effect of temperature on cellular reactions of Crassostrea virginica to the infection of avian arythrocytes. J Invertebr Pathol 23:22-37

Foley DA, Cheng TC (1975) A quantitative study of phagocytosis by hemolymph cells of the pelecypods Crassostrea virginica and Mecenaria mercenaria. J Invertebr Pathol 25:189-197

Harris JO, Maguire GB, Edwards S, Hindrum SM (1998) Effect of ammonia on the growth rate and oxygen consumption of juvenile greenlip abalone, Haliotis laevigata Donovan. Aquaculture 160:259-272

Hergenhahn HG, Söderhäll K (1985) $\alpha_{2}$-Macroglobulin-like activity in plasma of the crayfish Pacifastacus leniusculus. Comp Biochem Physiol 81(B):833-835

Hergenhahn HG, Aspan A, Söderhäll K (1987) Purification and characterization of a high-Mr proteinase inhibitor of pro-phenol oxidase activation from crayfish plasma. Biochem J 248:223-228

Holmblad T, Söderhäll K (1999) Cell adhesion molecules and antioxidative enzymes in a crustacean, possible role in immunity. Aquaculture 172:111-123

Hubert F, Van Der Knaap W, Noël T, Roch P (1996) Cytotoxic and antibacterial properties of Mytilus galloprovincialis, Ostrea edulis and Crassostrea gigas (bivalve mollusks) hemolymph. Aquat Living Resour 9:115-124

Klebanoff SJ (1982) Oxygen-dependent cytotoxic mechanisms of phagocytes. In: Gallin JI, Fauci AS (eds) Advances in host defence mechanisms I. Raven Press, New York, p 111-162

Lee KK, Liu PC, Chen YC, Huang CY (2001) The implication of ambient temperature with outbreak of vibriosis in cultured small abalone Haliotis diversicolor supertexta Lischke. J Thermal Biol 26:585-587

Le Moullac G, Haffner P (2000) Environmental factors affecting immune response in Crustacea. Aquaculture 191: 121-131

Le Moullac G, Soyez C, Saulnier D, Ansquer D, Avarre JC, Levy P (1998) Effect of hypoxia stress on the immune response and the resistance to Vibriosis of the shrimp Penaeus stylirostris. Fish Shellfish Immunol 8:621-629

Liu CH, Chen JC (2004) Effect of ammonia on the immune response of white shrimp Litopenaeus vannamei and its susceptibility to Vibrio alginolyticus. Fish Shellfish Immunol 16:321-334

Liu CH, Cheng W, Kuo CM, Chen JC (2004) Molecular cloning and characterisation of a cell adhesion molecule, peroxinectin, from the white shrimp Litopenaeus vannamei. Fish Shellfish Immunol 17:13-26 
Liu PC, Chen YC, Huang CY, Lee KK (2000) Virulence of Vibrio parahaemolyticus isolated from cultured small abalone, Haliotis diversicolor supexta, with withering syndrome. Lett Appl Microbiol 31:433-437

Martello LB, Friedman CS, Tjeerdema RS (2000) Combined effects of pentachlorophenol and salinity stress on phagocytic and chemotactic function in two species of abalone. Aquat Toxicol (Amst) 49:213-225

Pipe RK, Coles JA (1995) Environmental contaminants influencing immune function in marine bivalve molluscs. Fish Shellfish Immunol 5:581-595

Roch P (1999) Defense mechanisms and disease prevention in farmed marine invertebrates. Aquaculture 172:125-145

Sano T, Maniwa R (1962) Studies on the environmental factors having an influence on the growth of Haliotis discus hannai. Bull Tohoku Reg Fish Res Lab 21:79-86

Smith VJ, Johnston PA (1992) Differential haemotoxic effect of $\mathrm{PCB}$ congeners in the common shrimp, Crangon crangon. Comp Biochem Physiol C 101:641-649

Söderhäll K, Cerenius L, Johansson MW (1996) The prophe-

Editorial responsibility: Donald Evans,

Athens, Georgia, USA noloxidase activating system in invertebrates. In: Söderhäll K, Iwanaga SGR, Vasta GR (eds) New directions in invertebrate immunology. SOS Publications, Fair Haven, NJ, p 229-253

Song YL, Hsieh YT (1994) Immunostimulation of tiger shrimp (Penaeus monodon) hemocytes for generation of microbicidal substances: analysis of reactive oxygen species. Dev Comp Immunol 18:201-209

Trevors JC, Lusty CW (1985) A basic microputer program for calculating LD50 values. Water Air Soil Pollut 24:431-442

Weeks-Perkins, BA, Chansue N, Wong-Verelle D (1995) Assay of immune function in shrimp phagocytes: techniques used as indicators of pesticides exposure. In: Stolen JS, Fletcher TC, Smith SA, Zelikoff JT, Kaattari SL, Anderson RS, Söderhäll K, Weeks-Perkins BA (eds) Techniques in fish immunology, Vol 4. SOS Publications, Fair Haven, NJ, p 223-231

Yang HS, Ting YY (1986) Artificial propagation and culture of abalone (Haliotis diversicolor supertexta). Bull Taiwan Fish Res Inst 40:195-201

Submitted: December 24, 2003; Accepted: March 10, 2004 Proofs received from author(s): July 9, 2004 